\title{
Study on persistency of lactation in Holstein Friesian cattle
}

\author{
Kamal-Uddin Mandokhial, Hubdar Ali Kaleri, Rameez Raja Kaleri*, \\ Asma Kaleri, Abdul Sattar Safi, Azhar Hussain Kaleri and Muhammad \\ Akram Safi
}

Department of Animal Breeding and Genetics, Sindh Agriculture University, Tandojam-Pakistan

*Corresponding author's email: rameezkaleri@gmail.com

Citation

Kamal-Uddin Mandokhial, Hubdar Ali Kaleri, Rameez Raja Kaleri, Asma Kaleri, Abdul Sattar Safi, Azhar Hussain Kaleri and Muhammad Akram Safi. Study on persistency of lactation in Holstein Friesian cattle. Pure and Applied Biology. Vol. 6, Issue 1, pp159-163. http://dx.doi.org/10.19045/bspab.2017.60009

\begin{tabular}{llll}
\hline \hline Received: 01/11/2016 & Revised: 15/01/2017 & Accepted: 18/01/2017 & Online First: 23/01/2017 \\
\hline \hline
\end{tabular}

\section{Abstract}

This study was performed to analyses the persistency of lactation in Holstein Friesian cattle, by analyzing 168 lactation record from the period of 2006-2013 (8 years) at Government Dairy Farm Quetta, Baluchistan. The (PL) persistency of lactation was found lower in first lactation, while highest in $3^{\text {rd }}$ lactation in season winter and summer calves. The overall average (PL) was found $85.99 \pm 7.30 \%$ in winter calves and $83.79 \pm 7.27 \%$ in summer calves, whereas calving season effect was observed non-significant $(\mathrm{p}>0.05)$. The highest (PL) was found in Sire-D followed by Sire- B Sire_ A and Sire_C. The overall average (PL) in Holstein Friesian cattle was found $84.74 \pm 7.94 \%$. The Sire-wise effect of (PL) was found non-significant. The heritability estimates of (PL) was estimated low (0.094), while the correlation estimates was found higher among lactation length vs milk yield length (0.814), milk yield vs (PL) (0.883) and (PL) vs lactation length (0.747). It was concluded that results of current study for (PL) and Heritability of production traits were low to moderate for heritable traits, which can be improve through the proper environmental and manage mental conditions.

Keywords: Holstein Friesian; Persistency; Heritability; Correlation

\section{Introduction}

Livestock is important and renewable natural resource that plays major role the agricultural economy of Pakistan. Agriculture sector of Pakistan shares $21 \%$ to the total (GDP), whereas share of livestock sector is $11.8 \%$ to the total values of (GDP). It seems that livestock department is sharing about $55.91 \%$ to the total agricultural values of Pakistan [1]. The secretion of milk is a vital process of utilizing plant material and converting it into complete food. The milk serve as major source for our routine diet, which are important for nourishment and growth of human body. Baluchistan province has huge number of cattle about i.e. 8 million heads (GOP, 2013), but milk shortage still remain a serious problem due to low production of animals. In this way to fulfil the demand of milk in Baluchistan province high milk producing imported Holstein Frisian strain from Denmark for receiving high level production of milk at the Baluchistan. Lactation persistency is important trait of dairy animals that, is the capability of the cow to produce and 
maintain higher production of milk at higher level followed by its peak milk yield [2]. Heritability is key genetic parameter, which play major role in the selection of superior animals for future breeding plans. Heritability show the degree of proportion by which the individual genetic difference contributed to individual's own genetic individual differences, which can be observed in its (phenotype or physical individual differences) [2].

\section{Material and methods}

The 168 lactations milk record of Holstein Friesian cattle of Government Dairy Farm Quetta, Baluchistan, 6 lactations of each animal were recorded for analysed. Hand milking was used twice a day at the Farm. Animals having normal complete were added and incomplete recorded were discarded form the study. A cow having incomplete lactation record of any week that was estimated by averaging the previous available record, while animal having incomplete lactation record more than 8 week were discarded form the study described of [3]. For observing effect of season in (PL) and season divided in 2, season, winter the cows, which has calved in month of October till March) and summer (for the cows calved from April to September) .To observe the effect geneitcal effect on (PL) in Holstein Friesian cattle, cows were divided in to four groups as Group-A sired by Bull No. 542-F, B sired by Bull No. 675-F, C sired by Bull No. 710-F and D sired by Bull No. Laurier-E.T.

Method for analysing of (PL) of Holstein Friesian
The (PL) was analyzed by using the formula as suggested formula given by Ludwick and Peterson (1943).

\section{Method for estimation of (PL) of Holstein Friesian}

Heritability estimates of (PL) was performed by the formula as suggested by Becker, (1985).

\section{Results and discussion}

Parity-wise all average values of (PL) are presented in Table 1. Average (PL) of Holstein Friesian cattle for winter and summer season calves were $298.91 \pm 4.78^{*}$ and $297.11 \pm 4.427^{*}$ respectively. The highest average (PL) was found at 3 lactation, whereas it was found lowest in 6th lactation of winter as well as summer calves. The number of researchers have been reported for (PL) in different breeds. The results of [3-6], are higher and lower than the current study, who reported the (PL) $82.6 \%$ in Jersey, $85.22 \%$ in Anatolian buffalo, $87.34 \%$ in Karan Fries, $87 \%$ in NiliRavi and $81.62 \%$ in Buffalypso breed. Mostly, exotic buffaloes and cows are higher yield animal and are higher persistent than Bos indicus cows. The findings of [7-9] are in agreement with the current study, they reported higher lactation length in $3^{\text {rd }}$ lactation, while lower in $1^{\text {st }}$ lactation length and milk yield was found little bit decreased in $3^{\text {rd }}$ lactation with next calving. The results of [10] are in support with current study, who reported (PL) $68.73 \%$ Indian Red Sindhi Cattle and $63.65 \%$ in Indian Hariana cattle. Season of calving was found nonsignificantly $(p>0.05)$ affecting on the (PL) of Holstein Friesian cattle. 
Table 1. Average (PL) \% in Holstein Friesian cattle

\begin{tabular}{|l|l|l|l|l|}
\hline Parity & Summer Calvers & $\begin{array}{l}\text { Number of } \\
\text { Calvers }\end{array}$ & Winter Calvers & $\begin{array}{l}\text { Number of } \\
\text { Calvers }\end{array}$ \\
\hline $\mathbf{1}^{\text {st }}$ Lactation & $2664.58^{\mathrm{c}} \pm 294.07^{*}$ & 20 & $2698.44^{\mathrm{c}} \pm 482.75^{*}$ & 08 \\
\hline $\mathbf{2}^{\text {nd }}$ Lactation & $3476.25^{\mathrm{bc}} \pm 266.92^{*}$ & 16 & $3630.58^{\mathrm{b}} \pm 236.48^{*}$ & 12 \\
\hline $\mathbf{3}^{\text {rd }}$ Lactation & $4914.64^{\mathrm{a}} \pm 523.79^{*}$ & 14 & $4991.14^{\mathrm{a}} \pm 518.92^{*}$ & 14 \\
\hline $\mathbf{4}^{\text {th }}$ Lactation & $4096.86^{\mathrm{b}} \pm 197.88^{*}$ & 15 & $4236.00^{\mathrm{ab}} \pm 289.53^{*}$ & 13 \\
\hline $\mathbf{5}^{\text {th }}$ Lactation & $3438.31^{\mathrm{bc}} \pm 236.10^{\mathrm{ns}}$ & 16 & $3503.33^{\mathrm{b}} \pm 215.77^{\mathrm{ns}}$ & 12 \\
\hline $\mathbf{6}^{\text {th }}$ Lactation & $3215.06^{\mathrm{bc}} \pm 171.01^{*}$ & 17 & $3344.27^{\mathrm{b}} \pm 292.81^{*}$ & 11 \\
\hline Overall & $\mathbf{3 5 6 4 . 9 7} \pm \mathbf{7 6 3 . 2 6}^{*}$ & $\mathbf{9 8}$ & ${\mathbf{3 8 2 5 . 6 9} \pm \mathbf{8 0 4 . 0 1}^{*}}^{*}$ & $\mathbf{7 0}$ \\
\hline
\end{tabular}

*=T-Statistics significant $(\mathrm{p}<0.05)$

$\mathrm{ns}=\mathrm{T}-$ Statistics non-significant $(\mathrm{p}>0.05)$

The overall average of sire-wise (PL) is shown in table 2

The overall average of sire-wise (PL) in Holstein Friesian cattle was found $84.74 \pm$ 7.94 , the effect of sire in (PL) was observed non-significant $\quad(p>0.05)$. The results of current study are in conflict with [11, 12], who had reported significant effect of sire on the (PL), this difference may because of sire and small number of animals in herd. The results of current research are in accordance to results of [13], who estimated the 0.09 heritability for (PL) in Holstein cattle. The results of $[14,16]$ are relatively low than the results of current study, who estimated 0.01 to 0.07 in Egyptian Friesian and 0.05 to 0.08 heritability of (PL) in Germen Holstein. Results of [17, 19], are high than the present study, who reported the estimates of heritability of (PL) 0.02 to 0.51 in Canadian Holstein, 0.16 to 0.27 in Israel Holstein and 0.06 to 0.22 in Iranian Holstein Cattle. The difference among results of heritability is may be due to change in environmental conditions and managmetal methods [20].

Table 2. The Sire-wise (PL) and Heritability estimates in Holstein Friesian cattle

\begin{tabular}{|l|l|}
\hline Sire & Persistency $(\%)$ \\
\hline A & $84.62 \pm 8.10^{\text {ns }}$ \\
\hline B & $84.62 \pm 8.31^{\text {ns }}$ \\
\hline C & $84.63 \pm 8.02^{\text {ns }}$ \\
\hline D & $85.09 \pm 7.60^{\text {ns }}$ \\
\hline Overall & $84.74 \pm 7.94$ \\
\hline Heritability & 0.094 \\
\hline
\end{tabular}

$n s=$ non-significant $(p>0.05)$

The results for correlation co-efficient between lactation components of Holstein Friesian cattle are shown in Table 3

Results of current for correlation estimates was observed among milk yield and (PL) $(0.883)$ and lactation length and (PL) were found high positive. The estimations of current research are in partial accordance to [16], who had reported correlation among different (PL) traits from 0.13 to 0.46 in German Holstein Cattle. [10] has reported high positive correlation among that milk yield and (PL). There are various factors which effect on the production of cattle like age, breed, years of calving, sex, nutrition [21]. In a high temperature environment animal loss excessive heat production due to increasing stored heat in animals body, 
resulting in increased body temperature. While, radiation and environment temperature decrease the production of animal due to losses of heat of body by metabolism, feed intake and milk yields [22].

Table 3. The results for correlation estimates between milk yield and (PL) and lactation length and (PL)

\begin{tabular}{|l|c|}
\hline \multicolumn{1}{|c|}{ Lactations component } & Correlation \\
\hline Lactation persistency vs Lactation yield & 0.883 \\
\hline Lactation persistency vs Lactation length & 0.747 \\
\hline
\end{tabular}

\section{Conclusion}

It has been concluded that (PL) in Holstein Friesian cattle was found relatively lower, whereas season and sire effect was found non-significant. Heritability an estimate of (PL) was found low that is why it is important to improve nutrition and management practices for betterment of low heritable traits.

\section{Authors' contributions}

Conceived and designed the experiments: HA Kaleri, Performed the experiments: KU Mandokhail, RR Kaleri, AH Kaleri, AS Safi \& MA Safi, Analyzed the data: HA Kaleri, RR Kaleri \& A Kaleri, Contributed reagents/ materials/ analysis tools: KU Mandokhail, RR Kaleri \& A Kaleri, Wrote the paper: HA Kaleri \& RR Kaleri.

\section{References}

1. Farooq O (2014). Economic Survey of Pakistan 2013-14. Chapter-II. Agriculture ministry of finance, finance division. Pakistan. Section. Islamabad. Pakistan. Pp. 23-41.

2. Cobuci JA, Euclydes RF, Costa CN \& Torres RA (2009). Genetic evaluation for persistency of lactation Holstein cows using a random regression model. $J$ of Dairy Sci 45(3): 124 - 126.

3. Chaudhry HZ, Khan MS, Mohammad G \& Mustafa MI (2000). Persistency of lactation in Nili-Ravi Buffaloes. International J of Agri and Bio 02(3): 207-209.

4. Kumar A \& Singh V (2005). Genetic evaluation and reliability of persistency of milk production in Karan Fries. Indian society of Animal Breeding and Genetics Pp.6.

5. Hickson RE, Lopez-Villalobos N, Dalley DE, Clark DA \& Holmes CW (2006). Yields and persistency of lactation in Friesian and Jersey cows milked once daily. J of Dairy Sci 99(6):2017-24.

6. Tekerli MM, Kucukkebabci NH, Akalin \& Kocak S (2001). Effects of Environmental Factors on Some Milk Production Traits, Persistency and Calving Interval of Anatolian Buffaloes. Live Prod Sci 68(1-2): 271-281.

7. Lateef M, Gondal KZ, Younas M, Sarwar M, Mustafa MI \& Bashir MK (2008). Milk Production Potential of Pure Bred Holstein Friesian and Jersey cows in Subtropical Environment of Pakistan. Pak V J 28 (1): 9 - 12.

8. Barozai YH, Rafeeq M, Baloch H, Shahzad I, Hilal B, Abbas F \& Jehan M (2011). Study on Performance analysis of Holstein-Friesian cattle under intensive management at Government Dairy Farm, Pishin, Baluchistan Anim Bio and Anim. Husb 3(1): 65 - 70.

9. Nawaz, A, Nizamani AH, Marghazaini IB, Nasrullah \& Fatih A (2013). Influence of Genetic and Environmental Factors on Lactation performance of Holstein Friesian cattle in Baluchistan. $J$ of Plant and Anim Sci 23 (sup 1): 17 19.

10. Lennon HD \& Mixner JP (1957). Relation of lactation milk production in 
dairy cows to maximum initial milk yield and persistency of lactation. New Jersey Agricultural Experiment Station, Sussex Pp. 969 - 976.

11. Yadav AS \& Rathi SS (1991). Genetic evaluation of some performance traits in Hariana cattle. Asian J of Dairy Res 10(2): 103-110.

12. Shafiq M, Babar ME, Rehman A \& Ahmed G (1994). Factors Affecting Total milk yield, yield up to peak and persistency of first lactation in Sahiwal cows. P J of Agri Sci 3 (3): 228 - 232.

13. Kaya I (1996). Parameters estimates of Persistency of lactation and relationship of persistency with milk yield in Holstein Cattle. Ph.D. Thesis. Egr. Univ. Izmir. Turkey.

14. Fahim NH (2004). A Study on milk yield and persistency of a Holstein Herd in Egypt. M.Sc. Thesis. Fac. Agric. Cairo Univ. Egypt.

15. Abdel-Glil MF, Hussein K \& Tag ElDein MA (2004). Sire Evaluation of milk production traits of Friesian cattle in Egypt. $J$ of Agri Sci Mansoura University 29 (10): 5539.

16. Harder B, Bennewit J, Hinrichs D \& Klam E (2006). Genetic parameters for health traits and their relationship to different persistency traits in German Holstein dairy cattle. J of Dairy Sci 89: 3202 - 3212.

17. Muir BL, Fatehi J \& Schaeffer LR (2004). Genetic relationship between persistency and productive performance in $1^{\text {st }}$ lactation. Canadian Journal of Dairy Sciences 87: 3029-3037.

18. Weller JI, Ezra E \& Leitner G (2006). Genetic analysis of persistency in the Israeli Holstein population by the multitrait animal model. $J$ of Dairy Sci 89:2738-2746.

19. Kheirabadi K \& Alijani S (2014). Genetic Parameters for Milk Production and Persistency in the Iranian Holstein Population by the multitrait Random Regression Model. Archiv Tierzucht 57(12): $1-12$.

20. Javed K, Afzal M, Sattar A \& Mirza RH (2004). Environmental factors affecting milk yield in Friesian cows in Punjab, Pakistan. $P V J$ 24(2): (5861).

21. Johnson HD (1987). Bioclimatic Effects on growth, reproduction and milk production. In: Bioclimatology and the Adaptation of Livestock. Chapter 3. Elsevier Science Publishers Amsterdam pp. 35-57.

22. Johnson HD, Becker BA, Spencer KJ, Collier RJ \& Baille CA (1988). Effect of field and laboratory heat stress on milk and physiological response of lactating dairy cows supplemented with Sometribove (Bovine Somatotropin, BST). J of Dairy Sci Mtgs, Edmonton, Alberta. 